\title{
Photobiological Safety of the Sun
}

\begin{abstract}
This paper deals with the theme of photobiological safety of the sun. The Sun has in its spectrum ultraviolet, visible and infrared part of the radiance. This radiance could cause some injures of eye or skin.
\end{abstract}

Keywords: photobiological safety, sun, ultraviolet, infrared, blue light hazard

\section{Introduction}

The Sun is the central element of our solar system. It contains $99 \%$ of the mass of the whole system. It is a massive source of energy, which radiates in all fields of electromagnetic radiation, which affects all solar system bodies. It's a huge ball of hot plasma. With the passage of a few minutes to days the manifestations of its activities are reflected in the Earth's magnetic field and atmosphere. UV radiation from the Sun is dangerous for the living organisms. Strong solar flares can irretrievably harm the artificial satellite and the long-term changes in solar activity also affects the Earth's climate. The temperature on the surface of the Sun is $5700 \mathrm{~K}$, in the core is around 15 million Kelvin.

\section{Energy of the Sun}

The energy radiated by the Sun arises when the nuclear fusion reactions in its core. Every second approximately 700 million tons of hydrogen is converted into 695 million tons of helium, and the remaining 5 million tons of mass is converted into energy. Photons are generated in the core of the Sun, and it takes them up from 10000 to 170000 years before they reach the surface of the Sun from the core. It takes about 8 minutes to photons to reach the earth from the surface of the sun.

The best known value describing the sun energy hitting the earth is the solar constant. The solar constant has a value about $1367 \mathrm{~W} / \mathrm{m}^{-2}$. This value varies depending partly on the phases of the sun and also depending on perihelion and aphelion. The solar constant is the total flux of solar radiation in the entire range of the spectrum for the Earth's outside atmosphere (extraterrestrial), which is normally incident on a unit area of $1 \mathrm{~m}^{2}$ at a middle distance from the Sun to the Earth $(1 \mathrm{AU})$. Only a part of this energy falls on the ground. A large amount of radiation is absorbed in the atmosphere or it is reflected from the steam back into space. The amount of incident radiation on the ground depends on the state of the atmosphere - the quantity of water vapours and atmosphere dust contamination. The incident radiation due to these effects can be reduced up to $50 \%$. Solar radiance on the ground is about $1000 \mathrm{~W} / \mathrm{m}^{-2}$. From this value only $4 \%$ is ultraviolet (below $400 \mathrm{~nm}$ ), $42 \%$ is visible (400 to $700 \mathrm{~nm}$ ) and $54 \%$ is infrared (above 700 $\mathrm{nm})$. The solar spectrum on the ground (terrestrial) is different from the spectrum in the space (extraterrestrial). It is caused by the action of the ozone layer (it absorbs UV), oxygen, carbon dioxide and water vapours.

The average illuminance from the sun is about $98000 \mathrm{Ix}$. The colour temperature of the sun is about $5800 \mathrm{~K}$. This colour temperature corresponds to the temperature of the sun surface. $[3,4,5]$

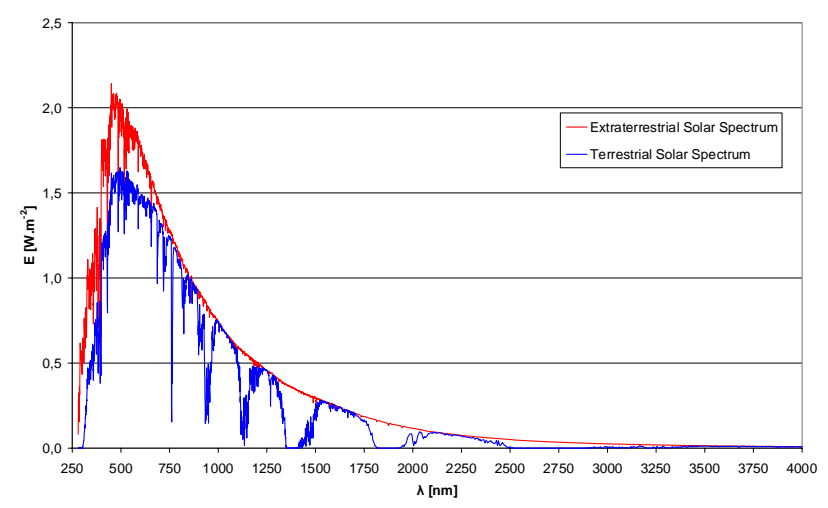

Fig.1. Comparison of extraterrestrial and terrestrial solar spectrum [3]

\section{Diseases caused by optical radiation}

\section{A. Photokeratitis}

Photokeratitis is known as snow blindness. It arises due to excessive exposure to the UV radiation. The range of effective spectrum causing photokeratitis is 200 to $400 \mathrm{~nm}$, the most effective range is between 200 and $320 \mathrm{~nm}$. It occurs after several hours after irradiation strong eye pain, photophobia, blepharospasm, there is usually a minor pathologic damage of conjunctiva and cornea, rarely, reduced vision.

You suffer from the photokeratitis is the feeling of sand in the eye. It is also necessary to protect eyes from the more intensive light. The status of the damage of the cornea is not different from UV radiation damage caused by welding (photoelectrica keratitis).

\section{B. Erythema}

Erythema is an acute skin inflammation caused by excessive UV radiation during one's stay in place with excessive ultraviolet radiation. The first symptoms start to occur after 6 to 8 hours exposure - pain and itching. The spectral range of UV radiation, which is involved in the formation of erythema is between 200 to $420 \mathrm{~nm}$. The most effective part of the spectrum is between 200 to $320 \mathrm{~nm}$, the peak values are around $254 \mathrm{~nm}$ and $295 \mathrm{~nm}$. Erythema may occur during the random exposure to germicidal lamps, mercury lamps and „mountain Sun“.

\section{Cataract}

The disease affects ophthalmic lens. It is manifested by the haze, which reduces the stream of light entering the eye. The exposure of eyes to UV radiation can cause the cataract. Cataract may be formed during the life thanks to sunlight. We can protect ourselves by using sunglasses with UV filter or contact lenses with UV filter. In a very high dose of irradiation it may occur within four hours. 
UVB radiation in the range of $290-320 \mathrm{~nm}$ has the greatest impact on formation of cataract caused by UV radiation. Peak value of the spectrum is about $305 \mathrm{~nm}$.

\section{Photoretinitis}

It is photochemical retina damage by excessive light. Photoretinitis is known as retina injury by blue light. Photochemical damage means that the incident light on the retina, can cause a chemical reaction. The blue light is a part of the spectrum with the highest energy content, which can reach the retina. It occurs in a long-term exposure (more than 10 seconds). The observable response appears after 12 hours after exposure. The greater radiation is the faster observable reaction appears. The damage is manifested by a blind spot on the retina in a place where a glowing object was reflected. The damage may be permanent, but the lighter damage of the retina can be healed.

The spectral range of sources causing damage by blue light is in range from 300 to $700 \mathrm{~nm}$ (the biggest damage is from 400 to $500 \mathrm{~nm}$ ). The peak value of the spectrum is around $445 \mathrm{~nm}$.

\section{E. Thermal damage in retina}

The thermal damage of the retina occurs during irradiation of an exposed eye which can be caused by the sun radiation or by an artificial light source, whose radiation is focused. The thermal damage of the retina at the point of sharpest vision (the macula) can cause of visual impairment in the direct radiation. When looking directly into the source of radiation the intensity of incident light on the retina may be so big and the holes can be burnt into the retina. The observer does not feel any pain and damage is observed after a few hours after irradiation. In a fortnight a scar occurs in a burned area of the retina and it remains throughout life. The disease is incurable. Both visible light and IR reflection influence the thermal damage of the retina a lot. Spectral range causing damage is in range from 400 to $1400 \mathrm{~nm}$. Conventional light sources cannot cause the damage of the retina. $[1,2]$

\section{Photobiological safety}

Photobiological safety deals with ČSN EN 62471 standard titled Photobiological safety of lamps and lamp systems. This standard is a translation of the European standard EN62471:2008. This standard provides knowledge to evaluate the light sources with regard to safety of their impact on living tissue. It specifies the exposure limits, the reference measurement technique and measurement methods of broad-spectrum sources used in the lighting technology. This standard works with the wavelength range $200-3000 \mathrm{~nm}$

To determine whether the light source can be dangerous, it is important to establish the limits of radiation exposure. The limits of exposure express the conditions in which most of people will not have due to repeated exposure adverse health effects. The specified values cannot be seen as the exact frontier ones between safe and dangerous areas. These values may have a different impact on different observers. They do not leave any negative health consequences for a healthy person. For those who have a high sensitivity to light, these limits cannot be applied and the determination of the limits to satisfy these individuals would be difficult. The diameter of the observer pupils, angular margins of measured source and measurement visual angle are the specific factors affecting the determination of the limits of retina exposure.
First it is important for the measurement to establish the distance of the light source from the measuring instrument. For general illumination sources it is recommended to indicate the limits of the exposure of light source in the distance in which they create the illuminance of $500 \mathrm{~lx}$.

Table 1. Emission limits for risk groups

\begin{tabular}{|c|c|c|c|}
\hline Risk & $\begin{array}{l}\text { Exempt } \\
\text { sources }\end{array}$ & $\begin{array}{l}\text { Low } \\
\text { risk }\end{array}$ & $\begin{array}{l}\text { Mod } \\
\text { risk }\end{array}$ \\
\hline Actinic UV $\left(\mathrm{E}_{\mathrm{s}}\left[\mathrm{W} \cdot \mathrm{m}^{-2}\right]\right)$ & $<0,001$ & $<0,003$ & $<0,03$ \\
\hline Near UV (EUvA $[$ W.m.'-2]) & $<10$ & $<33$ & $<100$ \\
\hline $\begin{array}{l}\text { Blue light, small source } \\
\left(E_{\text {UVA }}\left[\mathrm{W} \cdot \mathrm{m}^{-2}\right]\right)\end{array}$ & $<1,0$ & $<1,0$ & $<400$ \\
\hline Blue light $\left(\mathrm{L}_{B}\left[\mathrm{~W} \cdot \mathrm{m}^{-2} \cdot \mathrm{sr}^{-1}\right]\right)$ & $<100$ & $<10000$ & $<4.10^{\circ}$ \\
\hline $\begin{array}{l}\text { Retinal thermal } \\
\left(L_{R}\left[\mathrm{~W} \cdot \mathrm{m}^{-2} \cdot \mathrm{sr}^{-1}\right]\right)\end{array}$ & $<28000 / \alpha$ & $<28000 / \alpha$ & $<71000 / \alpha$ \\
\hline
\end{tabular}

\section{Methods and results}

Terrestrial spectrum of the Sun on a clear day was used for all this calculation. [3]

Near UV radiation in the range from 315 to $400 \mathrm{~nm}$ was evaluated according to the following formula for irradiance (EUVA):

$$
E_{U V A}=\sum_{315}^{400} E_{\lambda}(\lambda) \cdot \Delta \lambda,
$$

where: $E_{\lambda}(\lambda)$ is the terrestrial solar spectral irradiance in $\mathrm{W} \cdot \mathrm{m}^{-2} \cdot \mathrm{nm}^{-1}, \Delta \lambda$ is the bandwidth in $\mathrm{nm}$ [2]. The resulting value of solar spectrum for the near UV radiation responds to $E_{U V A}=46,23 \mathrm{~W} \cdot \mathrm{m}^{-2}$. This value responds to the mod risk group.

The permissible time of the eye UVA radiation exposure is calculated according to this formula:

$$
t_{\max } \leq \frac{10000}{E_{U V A}},
$$

where: $t_{\max }$ is permissible time of exposure in $\mathrm{s}, E_{U V A}$ is irradiance of near UV radiation in W. $\mathrm{m}^{-2}$ [2]. The resulting value of solar spectrum for the near UV radiation responds $\boldsymbol{t}_{\max }=217 \mathrm{~s}$. By this time the Sun does not cause any eye injury due to its UVA radiation.

For the blue light hazard is necessary to determine the angular subtense of source. The sources, which have angular substense less than 0,011 rad, are defined as small sources. The angular substense is defined by formula:

$$
\alpha=\frac{D}{l},
$$

where: $D$ is diameter of the Sun in $\mathrm{km}, /$ is a middle distance from Earth to Sun in $\mathrm{km}$. If we set for the $D=1,39.10^{6} \mathrm{~km}$ and $I=149,6 \cdot 10^{6} \mathrm{~km}$ the resulting $\alpha$ will be $\alpha=9,291.10^{-3}$ $\mathrm{rad}$. This value is lower than the value for common sources, so the Sun will be rated as a small light source. Blue light hazard for small light sources was evaluated by the following formula for irradiance $\left(E_{B}\right)$ :

$$
E_{B}=\sum_{300}^{700} E_{\lambda}(\lambda) \cdot B(\lambda) \cdot \Delta \lambda,
$$

where $E_{\lambda}(\lambda)$ is the terrestrial solar spectral irradiance in $\mathrm{W} \cdot \mathrm{m}^{-2} \cdot \mathrm{nm}^{-1}, B(\lambda)$ is the blue light hazard weighting function, 
$\Delta \lambda$ is the bandwidth in $\mathrm{nm}$ [2]. The resulting value of solar spectrum for the blue light hazard for small light source responds to $E_{B}=94,08 \mathrm{~W} \cdot \mathrm{m}^{-2}$. This value corresponds to the mod risk group.

The permissible time of eye exposure by blue light hazard is calculated according to this formula:

(5) $t_{\max } \leq \frac{100}{E_{B}}$,

where: $t_{\max }$ is permissible time of exposure in $\mathrm{s}, E_{B}$ is irradiance blue light in W.m ${ }^{-2}$ [2]. The resulting value of solar spectrum for blue light responds to $t_{\max }=1,06 \mathrm{~s}$. By this time the Sun does not cause any eye injury due to its blue light.

Retina thermal damage in the range from 380 to $1400 \mathrm{~nm}$ was evaluated according to the following formula for radiance $\left(L_{R}\right)$ :

(6) $L_{\mathrm{R}}=\sum_{380}^{1400} L_{\lambda} \cdot R(\lambda) \cdot \Delta \lambda$,

where $L_{\lambda}$ is the terrestrial solar spectral radiance in $\mathrm{W} \cdot \mathrm{m}$ ${ }^{2} \cdot \mathrm{sr}^{-1} \cdot \mathrm{nm}^{-1}, R(\lambda)$ is the burn hazard weighting function, $\Delta \lambda$ is the bandwidth in $\mathrm{nm}$ [2]. The resulting value of solar spectrum for retina thermal damage responds to $L_{R}=20,149 \mathrm{MW} \cdot \mathrm{m}^{-2} \cdot \mathrm{sr}^{-1}$. This value corresponds to the high risk group.

The permissible time of eye exposure by the thermal hazard is calculated according to this formula:

$$
t_{\max }=0, \sqrt{\frac{50000}{L_{R} \cdot \alpha}},
$$

where $L_{R}$ is radiance in $\mathrm{W} \cdot \mathrm{m}^{-2} \cdot \mathrm{sr}^{-1}$ and $\alpha$ is the angular subtense in radians [2]. The resulting value of solar spectrum for thermal damage of retina responds to $\boldsymbol{t}_{\max }=\mathbf{5 , 0 8} \mathrm{ms}$. By this time the Sun does not cause any eye injury due to its light.

\section{Conclusion}

The sun can cause thanks its radiation some injuries on human body. It is good to know, how much time it takes, than some injuries are made from sun radiation. In Table 2. we can see calculated risk values of thee risks a calculated values of permissible time. The most dangerous is retina thermal damage, which is very fast.
Table 2. Result values

\begin{tabular}{|l|l|l|l|l|}
\hline Risk & $\begin{array}{l}\text { Symbol } \\
\text { [Units] }\end{array}$ & $\begin{array}{l}\text { Result } \\
\text { value }\end{array}$ & $\begin{array}{l}\text { Permissible } \\
\text { time }[\mathbf{s}]\end{array}$ & $\begin{array}{l}\text { Risk } \\
\text { group }\end{array}$ \\
\hline $\begin{array}{l}\text { Near UV } \\
\text { hazard }\end{array}$ & EUva $\left[\mathrm{W} \cdot \mathrm{m}^{-2}\right]$ & 46,23 & 217 & $\begin{array}{l}\text { Mod } \\
\text { risk }\end{array}$ \\
\hline $\begin{array}{l}\text { Blue light } \\
\text { hazard }\end{array}$ & $\mathrm{E}_{\mathrm{B}}\left[\mathrm{W} \cdot \mathrm{m}^{-2}\right]$ & 94,08 & 1,06 & $\begin{array}{l}\text { Mod } \\
\text { risk }\end{array}$ \\
\hline $\begin{array}{l}\text { Retina } \\
\text { thermal } \\
\text { damage }\end{array}$ & $\begin{array}{l}\mathrm{L}_{\mathrm{R}} \\
{\left[\mathrm{MW} \cdot \mathrm{m}^{-2} \cdot \mathrm{sr}^{-1}\right]}\end{array}$ & 20,14 & $5,08 \cdot 10^{-3}$ & $\begin{array}{l}\text { High } \\
\text { risk }\end{array}$ \\
\hline
\end{tabular}

\section{Acknowledgment}

This research work has been carried out in the Centre for Research and Utilization of Renewable Energy (CVVOZE).Authors gratefully acknowledge financial support from the Ministry of Education, Youth and Sports of the Czech Republic under NPU I programme (project No. LO1210) and BUT specific research programme (project No. FEKT-S-14-2520).

\section{REFERENCES}

[1] ŠTĚPÁNEK, J. Fotobiologická bezpečnost světelných zdrojů a osvětlovacích soustav. Diplomová práce. Brno: Ústav elektroenergetiky FEKT VUT v Brně, 2014, 72 stran

[2] ČSN EN 62471. Fotobiologická bezpečnost světelných zdrojů a soustav světelných zdrojü. ÚNMZ, Červenec 2009

[3] ColleCtIVE OF AUTHORS. Standard Solar Spectra. [on line].PV Education.org, [citated 12.4.2015]. On WWW: http://www.pveducation.org/pvcdrom/appendices/standardsolar-spectra>

[4] COlLECTIVE OF AUTHORS. Slunce. [on line]. Astro.cz, [citated 12.4.2015]. On WWW: <http://www.astro.cz/naobloze/slunce.html>

[5] ColleCtive OF AUTHORS. Sluneční soustava: Slunce. [on line]. Aldebaran.cz, [citated 12.4.2015]. On WWW: <http://www.aldebaran.cz/astrofyzika/sunsystem/slunce.html>

\section{Authors:}

Ing. Jaroslav Štěpánek, Brno University of Technology - The Faculty of Electrical Engineering and Communication, Technická 3058/12 Czech Republic, e-mail: xstepa@stud.feec.vutbr.cz

Ing. Jan Škoda, Ph.D., Brno University of Technology - The Faculty of Electrical Engineering and Communication, Technická 3058/12 Czech Republic, e-mail: skoda@feec.vutbr.cz 